\title{
4 Dialogues on informality
}

\section{Land sharing as a sustainable approach to tenure security in Kiandutu informal settlement in Thika town, Kenya}

\author{
Peter Ngau and Philip Olale
}

\section{Introduction}

Lack of access to land and poorly defined tenure rights continue to characterize informality in urban areas in Africa. In most African countries, conventional land administration systems (land titling and individual ownership) that are inappropriate for their tenure context and unsustainable financially or in terms of available capacity remain dominant (Clarke, 2009). As a result, the overwhelming majority of African urban land transactions takes place in informal land markets (UNHabitat, 2010).

In spite of a growing acknowledgement of the importance of secure land tenure, in practice, establishing land rights in informal settlements often is a protracted engagement that pits the government against landowner(s) and slum dwellers. In the ensuing contestations, the government (at either national or local level) must also contend with its responsibility to maintain order and safety by exercising policing power and control over planned developments. The result is that the government finds itself in a stalemated position where it is unable to fully support the claims of either landowners or slum dwellers. Consequently, landowners cannot evict slum dwellers and proceed with development plans, while slum dwellers facing the omnipresent threat of eviction - remain limited in their ability to invest in housing improvement initiatives.

However, a growing emphasis on participatory and inclusive approaches targeting housing, infrastructure services, community assets, and social capital may offer new options in contemporary development discourse. The shift is captured both in theoretical works on urban planning (Friedmann, 1987; Healey, 2006; Watson, 2002) as well as more recently in the global development frameworks and conventions adopted since 2015. For instance, both the 17 Sustainable Development Goals (SDGs) of Agenda 2030 - which include stand-alone goals on inequality (SDG 10), justice (SDG 16), and inclusive, safe, resilient, and sustainable cities and human settlements (SDG 11) - and the subsequently adopted New Urban Agenda were formulated through extensive processes of consultation (Rudd et al., 2018).

These approaches move planning from a narrow, technical, and procedural focus, towards rights-based and collaborative models for achieving common purposes in 
the shared spaces of our fragmented societies. Moreover, while previous development agendas such as the Millennium Development Goals did not mention land directly, the SDGs include six goals with a significant land component, ranging from goals on poverty (SDG 1), hunger (SDG 2), gender equity (SDG 5), and life on land (SDG 15), in addition to SDGs 11 and 16 mentioned earlier. However, without good land governance and well-functioning land administration systems in place, these goals will remain only that (Enemark, 2016, pp. 3-4).

Focusing on Kiandutu informal settlement in the town of Thika, Kenya, this chapter presents the findings of a co-production approach to seeking solutions for improving tenure security and land governance. Building on a long-standing collaboration with stakeholders in the Municipality of Thika, the Centre for Urban Research Innovations (CURI) at the University of Nairobi organized a 'CityLab' to explore the benefits and challenges to land sharing as a sustainable approach to tenure security for urban slum dwellers occupying public land.

\section{Context}

\section{The urban land challenge in Africa}

The majority of urban dwellers in Africa lack secure access to land. This absence does not just have an impact on housing conditions, but also on people's levels of poverty and access to services and health, all of which are compounded by the effects of rapid urbanization and climate change. Land challenges for informal dwellers manifest in many ways - including restricted access to land, inequalities in landownership, and insecurity of tenure - and have resulted in environmental, social, economic, and political problems, including deterioration of land quality, squatting and landlessness, disinheritance of groups and individuals, urban squalor, and conflict (UN-Habitat, 2010).

Various scholars have argued for the need to improve tenure security for the urban poor so that they have sustainable access to land, and, in turn, incentives towards investment and improvement of their housing and living environment (Olale, 2015; Durand-Lasserve \& Royston, 2002). Long considered an essential public good and basic foundation for development, land and shelter are widely seen as preconditions to securing basic living conditions and livelihood opportunities, as well as a means of reducing poverty and gender inequality (Rakodi, 2014). Komjathy et al. (2001) define access to land as the right or opportunity to use, manage, or control land and its resources. 'Access' thus refers to the ability to use land and other natural resources, to control resources and transfer rights to the land, and to take advantage of other opportunities such as access to credit.

Scholars such as De Soto (2000) have argued that property rights play a key role in shaping economic decision-making and increasing productivity of those living in informal settlements. While some rights can be accessed without necessarily possessing formal landownership (e.g., the right to use, occupy, and develop/ cultivate/produce, and the right to access basic services, including sanitation), key levers like formal credit can only be accessed with formal title as collateral. 
Thus, enhancing tenure security for informal settlement residents is integral to a range of different policies and interventions, such as land titling programmes and urban upgrading, many of which are supported by extensive international funding (Buckley \& Kalarickal, 2006).

However, practice shows that land tenure is a relative and contested concept. With different perceptions and understandings on the ground, and a range of actors and practices involved, policy interventions around land tenure have resulted in varied and unintended outcomes (Payne, 2002; Payne et al., 2009; Napier et al., 2013). Meanwhile, most African countries continue to adhere to conventional land administration systems, such as land titling and individual ownership, which are inappropriate to the African tenure context and unsustainable financially and in terms of capacity to administer (Clarke, 2009). Moreover, stagnancy in the management and administration of land remains a massive challenge facing African governments and cities today (Durand-Lasserve, 2004).

Resolving land rights in informal settlements is a protracted engagement that usually involves the government, landowner(s), and slum dwellers. In cases where informal settlements have arisen on private land, private landowners generally take the view that government must protect their legal rights, and assist in clearing slums so the landowners can use their land as they see fit. In many other cases, informal settlements have arisen on public or government-owned land. In both cases, slum dwellers variously argue that they have a claim to the land through prolonged habitation, that they have nowhere to go without losing their means of livelihood, that the law is unjust if so many must suffer so that a few may benefit, and that the government has both a social and constitutional responsibility to provide them with proper housing. Such claims illustrate the global shift towards rights-based approaches to development, which recognize de facto land access, occupation, and the use of urban space as matters of urban citizenship in the context of a 'right to the city' (Vogiazides, 2012).

While most African governments formally adhere to both legal and rights-based understandings of land tenure in their constitutional laws and urban policies, this often does not translate to practice. In best case scenarios, this leads to the continued growth of informal settlements. In the worst cases, governments opt for the eradication of slums, replacing them with planned housing developments (Huchzermeyer, 2011). In the ensuing contestations, governments often find themselves in the awkward position of being both the landowner and a supposedly neutral arbiter and protector of citizen's rights. Further, the government, at either national or local levels, also has a responsibility to maintain order and safety through planned development, where government exercises its police power/development control.

Arising from these conflicting rationalities, a dialogue-oriented approach is germane in offering pragmatic solutions to land governance, especially when it is clear that none of the parties is willing to surrender its claims or positions. This study provided such a dialogue-oriented approach to unlocking tenure security in Kiandutu informal settlement in Kenya, through an exploration of the concept of 'land sharing' in a local CityLab. 


\section{Tenure security in urban Kenya: the post-colonial challenge}

Kenya has a population of 47.6 million persons based on 2019 population census data (KNBS, 2019). The previous census in 2009 showed the population at 38.6 million, an increase from 28.7 million in 1999, 21.4 million in 1989, and 15.3 million 1979 (GoK, 2009). The urban population was last estimated at 14.5 million, with an annual growth rate of $4.2 \%$ (KNBS, 2009). ${ }^{1}$ Of Kenya's urban population, about $65 \%$ live in informal settlements (Olale \& Opiyo, 2017). In Nairobi, the capital city, about $60 \%$ of the population lives in over 180 different informal settlements. This phenomenon of rapid urbanization facilitated by both natural factors (natural population growth within the urban areas) and exogenous factors (forced rural-urban migration or urban-urban migration due to a plethora of factors including poverty, joblessness, and conflict) has led to the contemporary growth of informal settlements in Kenya (Tacoli et al., 2015).

Increasing urban populations in Kenya continue to put pressure on infrastructure and other basic services such as housing, water, sanitation, and land. Unlike other basic services, however, land is a fixed asset, and therefore captive to its use (i.e., no longer available for any other use). This complexity particular to land increases the need for land management administration tools and policies whose creativity and sustainability can match the rapid rate of urbanization.

According to the Constitution of Kenya 2010, every person has the right to accessible and adequate housing, and a reasonable standard of sanitation. However, it has become increasingly difficult for the government to provide sufficient affordable housing units for the urban poor. Kenya Vision $2030^{2}$ notes that the government is only able to meet $23 \%$ of the annual demand of 150,000 affordable housing units. The lack of appropriate and affordable housing has forced thousands into overcrowded and expanding informal settlements, and even left many homeless. Factors such as rapid population growth, stringent planning regulations, restrictive building standards, high costs of infrastructure, poverty, and perhaps most fundamentally, lack of affordable land, compound the problem.

Article 60 of Kenya's Constitution establishes equitable access to land as a principle in which land is held, used, and managed (GoK, 2010). Since the adoption of the 2010 Constitution, Kenya has further ratified several global development agreements, such as Agenda 2030 and the New Urban Agenda, and adopted a series of institutional and policy frameworks to implement these agendas in the field of housing and basic services, urban and human settlements infrastructure, land, urban and regional planning, urban economy, environmentally sustainable and resilient urban and human settlements, and urban governance (GoK, 2017).

Despite all this, lack of access to land and poorly defined tenure rights continue to characterize informality in Kenya's urban areas. While some $66 \%$ of the total urban population lives in informal settlements, conventional recognized systems like land titling and individual ownership only apply to just over a third of cases. This leaves the majority of Kenya's urban citizens to the uncertainties defining the informal land administration system. In fact, Kenya's National Land Policy ${ }^{3}$ 
recognizes the absence of security of tenure and planning as the essence of 'informal', 'spontaneous', or 'squatter' settlements (GoK, 2009).

Kenya's current land question is rooted in its colonial history, and three distinct but interrelated processes that shaped land management provide important context (Sorrenson, 1967). The first process was the alienation and acquisition of land in preparation of the establishment of a colonial state. What followed was the imposition of English property law, with its support of title and private property rights in those alienated areas. Those processes gave rise to distinct but related sets of problems regarding access and control of land, thereby laying the basis for today's complex land matrix. In urban areas, this matrix is characterized by limited access to land, unsuitable tenure systems, and increasing illegal settlements in the form of slums. Meanwhile, those who can access titled land tenure use it as a store of wealth against which they leverage financial assistance such as loans, making tenure security a fundamental principle of housing rights advocacy in informal settlements, as well as legal protection against forced eviction, harassment, and other threats that symbolize rising urban inequalities (Syagga, 2011).

\section{Defining land sharing}

Land sharing is a negotiated agreement between landowners, developers, and land occupants, to partition and share a plot of land, even in the absence of legal tenure (Angel \& Boonyabancha, 1988). The practice of land sharing first emerged in Bangkok in the context of a booming property market that led to intense conflicts between landowners and landholders (Rabé, 2010; Angel \& Boonyabancha, 1988; Boonyabancha, 2005; D'Cruz et al., 2009).

Land sharing becomes a useful option between landlords and slum dwellers when the intentions of a landlord to repossess the land become clear to the resident, and the resident decides to resist or contest the imminent eviction or loss of the land they occupy (Angel \& Boonyabancha, 1988). According to Parry (2015), land sharing is a compromise solution, whereby the owners of land that is encroached upon and the community that lives there collectively agree to split the land between them. Parry (2015) further elaborates that in this scenario, the community buys, leases, or receives one portion of the contested land for free, while the more commercially attractive part of the site is returned to the developer or owner. The notion of land sharing advanced by Parry (2015) is similar to that discussed by Rabé (2005), who notes that in Cambodia, land sharing also cedes the most commercially viable portion of the land to the landowner, with the remaining portions leased, sold, or given to land occupants for legal occupation.

Although the land-sharing option is not suitable for all cases of land-use conflict, it can be a flexible and successful strategy. Using this approach, the owner of land occupied by an informal settlement is encouraged to lease or sell part of the property to the occupants at a rate below market value, allowing the owner to recover and develop the remaining land. Parry (2015) also observes that the land-sharing approach catalyses occupants to take the initiative to considerably 
improve their settlements. In most cases of land sharing, the slum dwellers organize themselves into a viable organization, initiate negotiations with the landowner, and then share the land - allocating the prime parcels of land to the owner, and using the remaining land for their housing. The housing development that arises under this arrangement is generally more organized than in cases where land is occupied without engaging the residents or landowner (Srinivas, 2015).

Finally, land sharing offers part of a solution for a larger problem, in that landsharing arrangements can serve as a step towards providing universal access to housing, while also creating an opportunity to remodel the city in a more participatory and inclusive way (Abott, 1996). However, to be successful, land sharing must be accompanied by reforms to regulate the land market, restrict land uses, allow higher building standards, and enable implementation of incremental development (Montressor, 2015).

\section{The Kiandutu CityLab project}

The Kiandutu CityLab is part of a larger research drive undertaken by the Centre for Urban Research Innovations (CURI), at the University of Nairobi in partnership with stakeholders in the Municipality of Thika, Kenya over the last eight years. The overall purpose of the larger project is to facilitate the consideration and adoption of policy strategies that can respond sustainably to the lack of affordable shelter and to land-access constraints faced by the urban poor. The collaboration, which goes back to 2011, has involved the community of the Kiandutu informal settlement, the NGO Muungano Support Trust (MuST), the Thika Municipality, and the University of Nairobi represented by CURI. The community living in Kiandutu are members of the Federation of Slum Dwellers in Kenya called Munnano wa Wanavijiji, while MuST is a member of Slum Dwellers International (SDI).

The collaboration emerged in 2011 with the Kiandutu community and MuST's mutual interest in the upgrading of the informal settlement through processes such as mobilization, enumeration, group savings, demonstration of housing improvement, and advocacy for tenure security. The Thika Municipality and County Government of Kiambu were also interested in improving urban public services such as water supply, sanitation, electricity, and solid waste management in Kiandutu. However, while the former Thika Municipality (pre-2013) and the first County Government of Kiambu (2013-2018) were positively engaged with the programme for slum upgrading and land tenure security in Kiandutu settlement, the current County Government of Kiambu (2018-present) has been hesitant to engage in the partnership for slum upgrading.

As a member of the Association of Africa Planning Schools (AAPS), CURI/ DURP intends to transform urban planning education and practice in Africa by equipping upcoming urban planners with the relevant skills and methodology to address the challenges facing the African city. That is, using participatory community planning studios so that young planners (students) and community members 
can actively engage in problem solving and urban revitalization of informal settlements. The university team thus supports community mobilization and slum upgrading by deploying scientific and technical skills for mapping settlements and infrastructure services, conducting household surveys, and preparing layout plans for informal settlement upgrading.

From 2015-2016, with support from the Global Land Tools Network (GLTN) Urban CSO Cluster Project, CURI, working with partners SDI and AAPS, conducted a literature review and rapid survey on alternatives to land access in Kiandutu (Olale \& Opiyo, 2017). Through rapid research, we gathered existing literature and secondary data from local SDI civil society partners. The survey report showed the status of the land and the available approaches towards land access in Kiandutu settlement. Using this data, we prepared a policy brief to advise the Kiandutu community on the various options it could leverage to access land and improve tenure security, which included land sharing. Prior to the report, the community had engaged in endless contestation over land tenure in an ad hoc manner with various stakeholders since 1969.

While the report represented the first structured basis for a discussion on sustainable tenure security, it also became clear that it was primarily based on existing policy and legal frameworks and discussions with Kiambu County (the custodians of the land). In other words, it lacked adequate input from the community members living in the informal settlement. As such, we saw the need for a dialogue-based participatory framework on land sharing, which would become the Kiandutu CityLab. The questions at the heart of the CityLab dialogue, and to which the bulk of this chapter is addressed, are:

- What are the prospects for land sharing in Kiandutu informal settlement?

- How do existing land-use systems and structures in Kiandutu informal settlement influence a land-sharing approach?

- What might an acceptable physical-planning model based on the principles of land sharing look like in terms of densification, mixed-use housing layout, housing reconstruction, infrastructure, and amenities provision?

\section{Methodology}

CityLabs have emerged as forums for practical learning that provide participants with hands-on understanding of urban challenges, especially from a spatial planning perspective. Scholl and Kemp (2016) argue that CityLabs may be used to generate ideas for city projects and to explore visions of sustainability, democracy, and devolution of public tasks and responsibilities. CityLabs can also be oriented towards actions such as idea-generation and evaluation, and/or to experiment with new forms of urban planning (Scholl \& Kemp, 2016).

The Kiandutu CityLab commenced in November 2017 with a literature review, followed by community sensitization and stakeholder identification, which were complete by January 2018. While all partners attended the preparatory meetings at the CityLab's initial phase (through January 2018), the intensification of 
campaigns for the national, county, and local elections across the country caused county officials, politicians, and local administrators to withdraw from the joint stakeholder workshops, stating that 'the land question' was too emotive to engage in during a campaign period.

Nonetheless, a series of three CityLab workshops targeting Kiandutu informal settlement residents in Thika town were organized in March 2018 within Kiandutu settlement (at Muungano Hall). Workshop participants were chosen by gender and age, creating one workshop for women, one for youth, and one for men, each with 12 participants. The aim was to enable optimal engagement in a free atmosphere, and to better capture divergent and sometimes gender-specific tenure issues. Participants came from all the settlement's villages, and included individuals from the set criteria (i.e., structure owners/landlords, tenants, business operators, service providers, and community leaders).

The workshops all included two main sessions: a general discussion session and a planning session. During the general discussion session, participants were taken through various models of accessing tenure security, including resettlement, community land buying, adverse possession, and land sharing. The discussion was however centred on the land-sharing option, which was extensively explained to the participants, who were later solicited for their ideas and responses with regard to the land-sharing process and its applicability in Kiandutu settlement. The planning session mainly focused on the land-use planning aspects of the landsharing process, including aspects of survey, densification, and housing layout/ reconstruction. During this session, participants used a printed base map to show their preferred areas for settlement, to be issued back to the County Government.

The outputs from the workshops included an articulation of the stakeholders' ideas about land sharing, especially from a youth- and gender-based lens. The data were collected through note-taking and also recorded using a Dictaphone, and later transcribed and organized in themes based on the workshop discussion questions. The resultant data from the workshops were triangulated to arrive at common themes of argument from the three workshops.

The following sections provide background and historical context to the Kiandutu informal settlement, its land governance, and settlement characteristics, before turning to the outcomes of the CityLab workshops.

\section{Background to Kiandutu informal settlement}

With a total area of 110 acres, Kiandutu is the largest informal settlement in Thika town, from which it is located two kilometres to the southeast. It lies within Hospital ward, Thika Town Constituency, just off Garissa Road (A3). Administratively, Kiandutu falls under Kianjau Sub-Location of Thika Sub-County, Kiambu County (Figure 4.1).

Currently Kiandutu is made up of ten villages: Biashara, Centre Base, Kianjau, Mikinduri, Molo A, Molo B, Mosque, Mtatu A, Mtatu B, and Stage Wariah (Figure 4.2). Started as a milk depot in 1978, Biashara village later developed into a business hub for the settlement, and is the location of Kiandutu market. Kianjau 
THIKA TOWN LOCATION CONTEXT

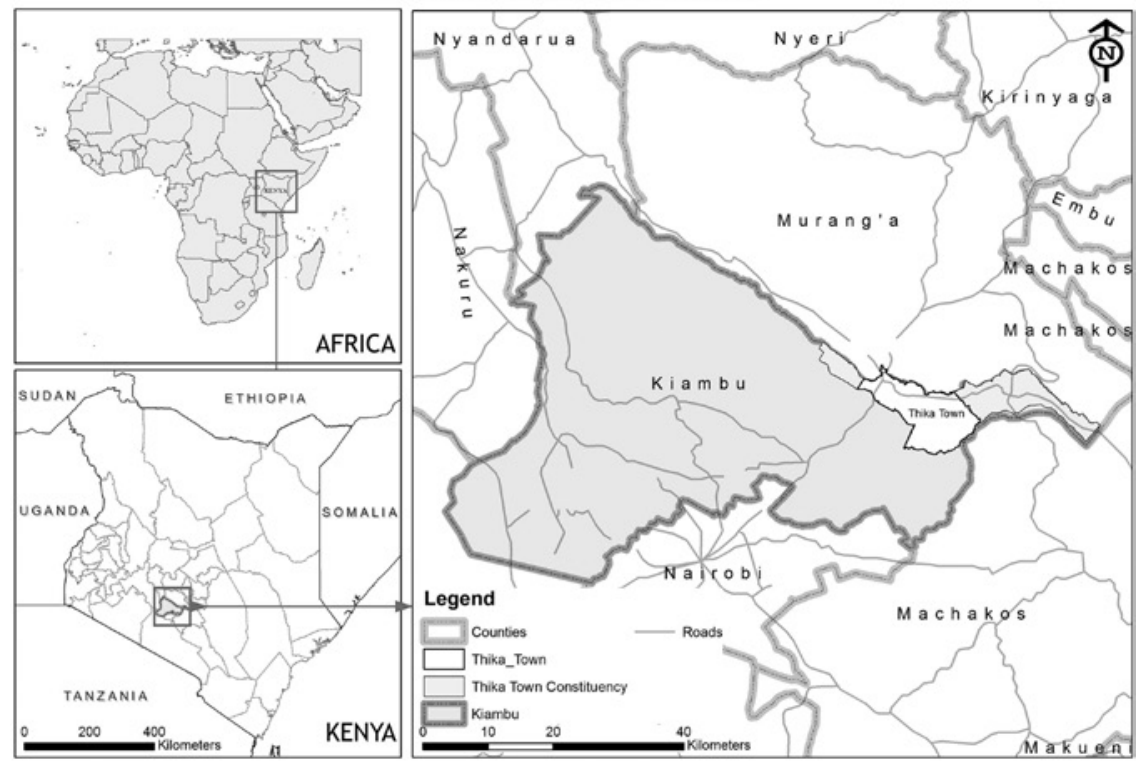

LOCATION CONTEXT OF KIANDUTU IN THIKA TOWN

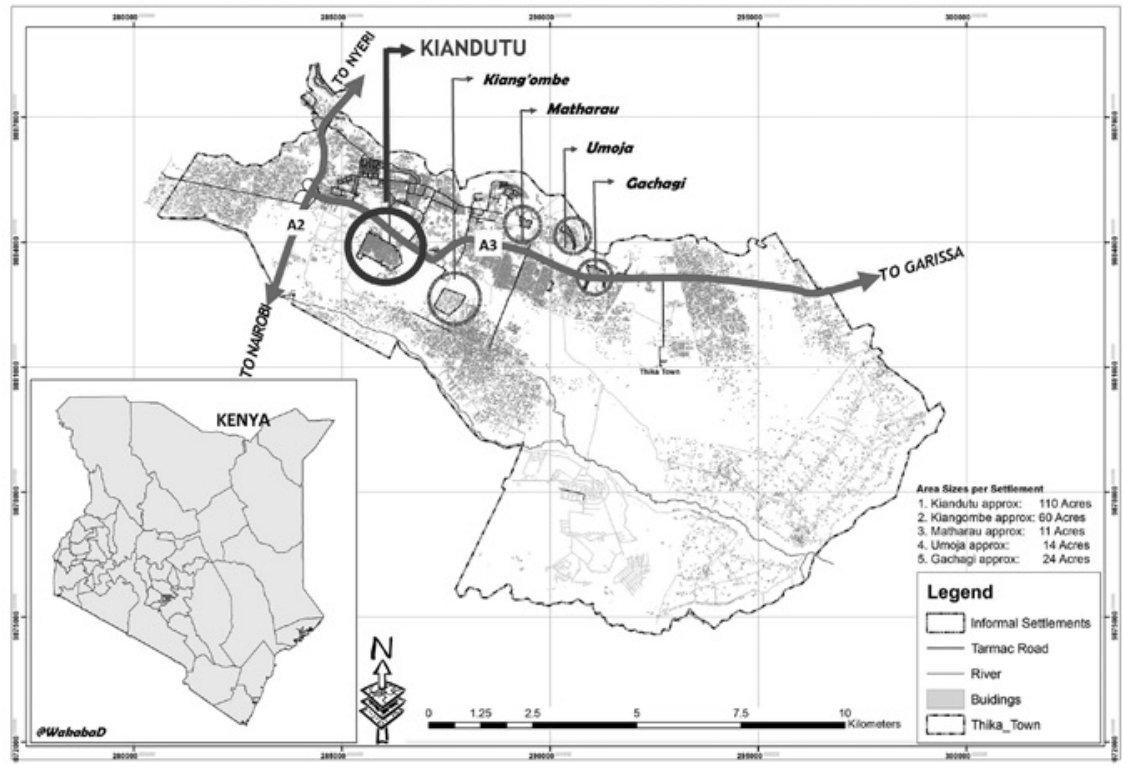

Figure 4.1 Location of Kiandutu

Source: CURI, 2013 


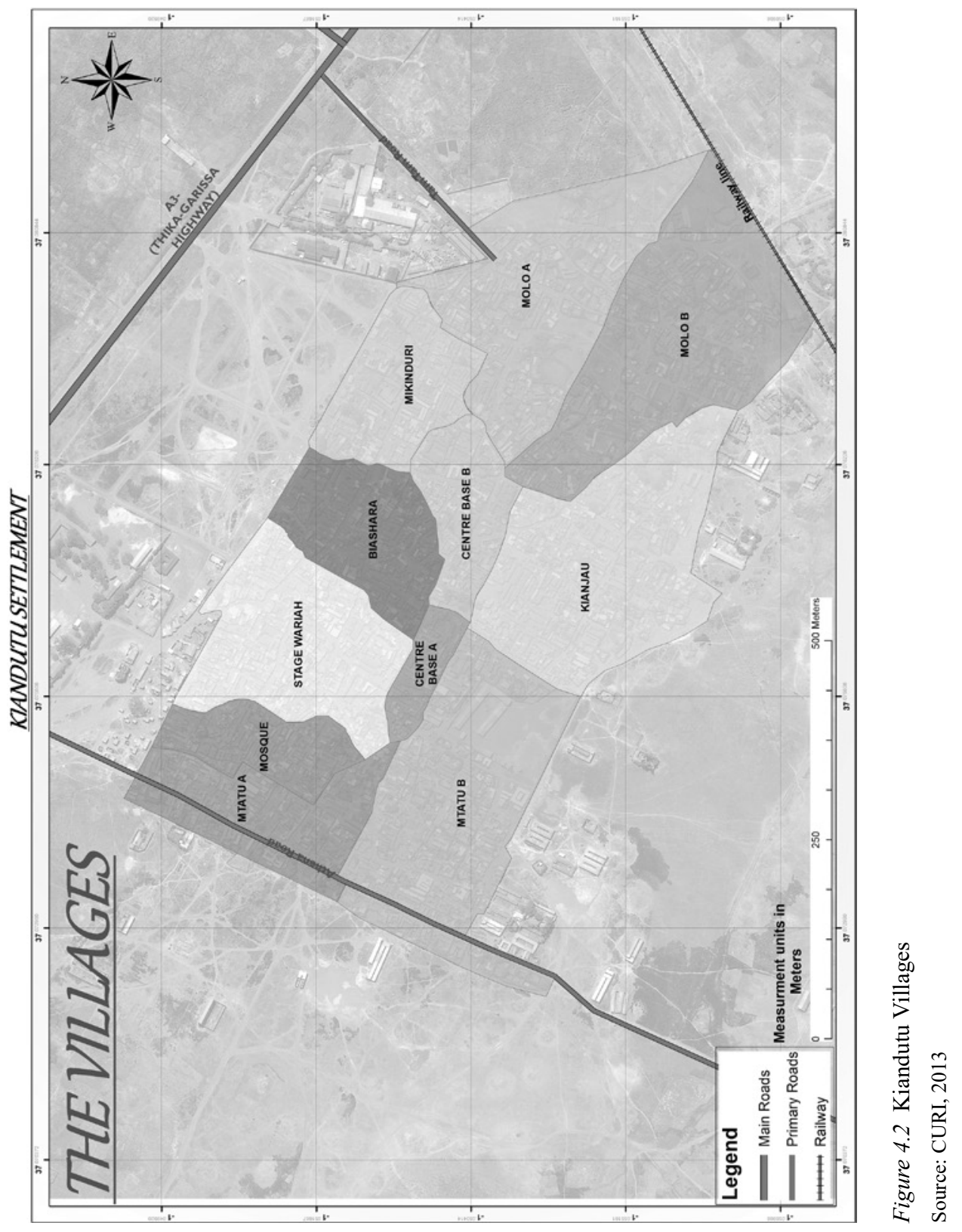


village was previously known as Nyakinyua, named after a women's group that operated a community water point. Mikinduri village was named after a type of indigenous tree by the Kikuyu people, who in 1963 formed Kianjau Farmers' Cooperative Society. These Cooperative Society members are believed to be the 'original' settlers of Kiandutu, and their children and grandchildren form the majority of Kiandutu residents. People displaced during the political clashes in Molo area of Kenya in 1997 founded Molo village, while Muslims who constructed a mosque in 1978 started Mosque village. Stage Wariah village was named after its Somali residents, who settled there after establishing a market for goats and sheep.

Kiandutu's climate is moderate tropical, with typical average temperatures of $25^{\circ} \mathrm{C}$ during the day and an average annual rainfall ranging between $900 \mathrm{~mm}$ and $1,250 \mathrm{~mm}$. Kiandutu's topography slopes northwest to southeast, where Molo village is located, making Molo flood-prone in heavy downpours.

\section{History}

Kiandutu settlement was established in 1969, when cooperative societies began buying land from European settlers after independence. The Europeans who were rearing cattle and growing coffee on the land surrendered it to their workers, who formed the Kianjau Cooperative Society. The Society's mandate was to construct new structures and collect rent. After a modest start in which many members built homes for themselves and began letting some rooms, further housing developments took the form of mud tenements, which were built with little space between them.

In the early 1970s, the national government acquired 100 acres of the Kianjau Cooperative Society's approximate 800 acres, compensating cooperative members with land in Makongeni Phase IV estate. Government intended to use those 100 acres - which constitute the current site of Kiandutu settlement - to establish an army barracks. However, army officials declined the government's offer of the 100 acres, instead establishing barracks farther along Garissa Highway, away from the Thika town centre. The Municipal Council of Thika thus took custody of the 100 acres, and began subdividing and selling it to private individuals. At this point, Kianjau Cooperative Society members raised grievances about the replacement land they had received in Makongeni Phase IV estate, which they said was smaller than the Kiandutu plot. Due to this dispute, some members of the Cooperative Society refused to leave Kiandutu, while others who had left for Makongeni Phase IV estate returned.

This resulted in two separate communities being forced to share informally subdivided land, a situation that has led to conflicts between the residents and the government. The designated custodian of the land at the time, the Municipal Council of Thika ${ }^{4}$ was pulled into legal battles over access to the land.

\section{Settlement population and demography}

Establishing an accurate population size for any informal settlement is never a straightforward affair. This is due both to the dynamics of residency for the 
majority of slum dwellers, and the variations in methodology used for data collection. Unsurprisingly, Kiandutu settlement lacks a single consistent population count. The last national population census in 2009 reported a population of 13,240 residents and 5,086 households. The latest figures from a 2011 enumeration by Muungano Support Trust (MuST), a slum dwellers organization, indicated an estimated population of 17,337, with 8,307 households. A settlement enumeration carried out in 2015 by Slum Dwellers International Kenya reported a total population of 14,532 residents, with 5,693 households. The variation in population size is attributed to the dynamic changes in informal settlements, such as high turnover of tenants, who either move to other settlements or return to their villages, especially during official government census-taking. Demographically, Kiandutu's population mirrors the national pyramid, with the majority of the population below 15 years (CURI, 2013).

Using an annual informal settlement growth rate of 5\%, and holding all factors constant, Kiandutu's total population is expected to reach 43,809 by the year 2030 , resulting in a population density of 47,515 persons per $\mathrm{km}^{2}$ on the current $0.922 \mathrm{~km}^{2}$ (92.2 acres) area covered by the settlement (Figure 4.3). Such an increase will not only create overwhelming space contestation, but also strain existing infrastructure. With no currently recognized form of tenure security for residents, settlement improvement may prove unattainable, putting the sustainability and health of this community at great risk.

\section{Land administration and management}

Land administration and management in Kiandutu is based on existing formal and informal institutional dynamics. The formal institutions include a full spectrum of both the national and county government structures, with the Chief serving as the most local-level of representation. ${ }^{5}$ Within the informal settlement, the Chief is usually assisted by village elders representing each village cluster. Meanwhile, the informal institutions are largely constituted by various interest groups, such as association of tenants, structure owners, Community Based Organizations (e.g., Muungano Wa wanavijiji), and service providers such as water vendors.

Today Kiandutu informal settlement occupies public land that falls under the custody of the County Government of Kiambu. Under its first (2012-2017) administration, the County Government demonstrated willingness to engage in a land-sharing approach with the community, offering to provide community facilities and utilities (as discussed earlier). However, a new County Government administration was elected in 2017, and this administration has not shown the same level of political will or appetite for enabling land-sharing arrangements.

Currently, Kiandutu lacks a structured, formal land-management and tenure system. Each cluster of residents in the different villages have laid claim to the land where they reside. Such claims are based on land as currently occupied, albeit with no official government-issued ownership documents. All land transactions, from subdivision to allocation, occur informally through a 'gentleman's agreement' in which payment is presented in exchange for possession or use of a 


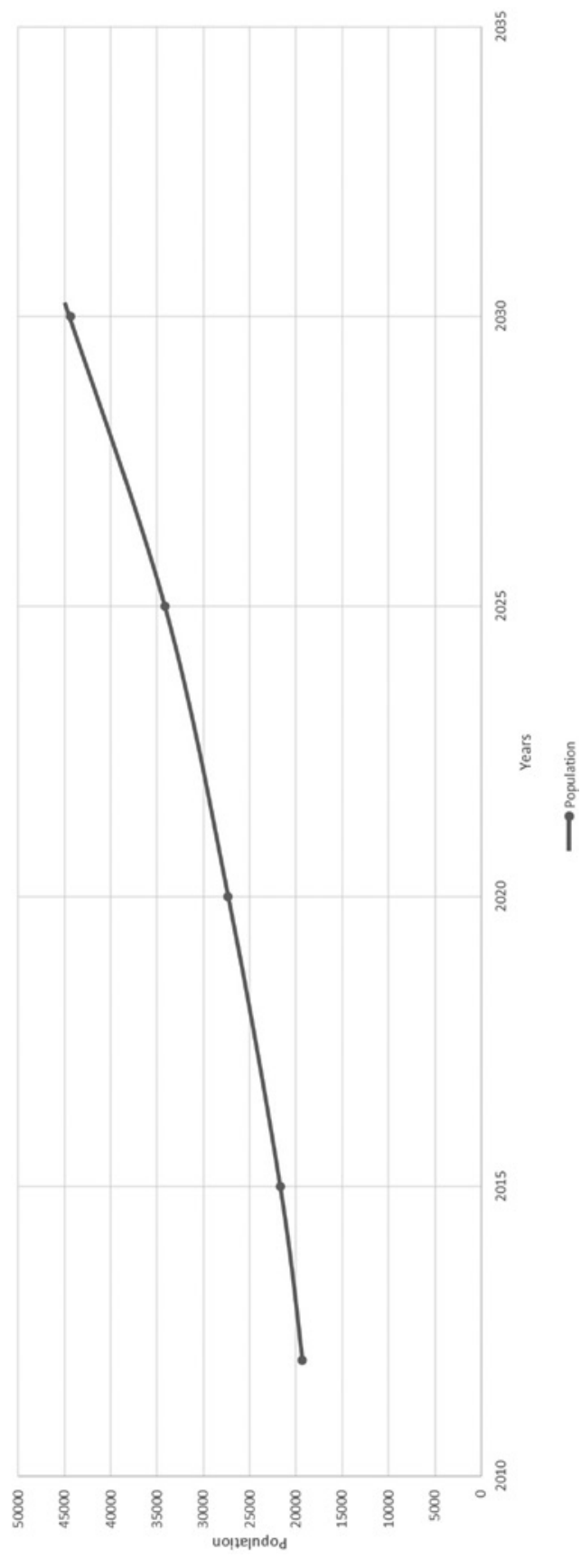

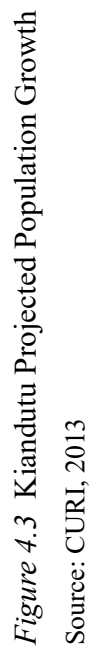


piece of land. Such 'ownership' can only be legitimized by the elders/chiefs in the village, who were the land's original settlers. With the settlement's growth over time, inhabited areas have extended into private land adjacent to the settlement.

Because Kiandutu lacks any structured or centralized system of land management, landownership record systems are also a challenge. By law, details of ownership and use must be recorded in a title deed registration system that is linked to cadastre information (GoK, 2012). ${ }^{6}$ However, the reality in Kiandutu is that this is not happening, and the established 'owners' ultimately determine the use and boundaries of a piece of land, with no legally recorded proof of these details. This has led to haphazard subdivisions, the development of informal structures without accompanying infrastructure provision, and frequent and deep conflict between occupants and owners.

\section{Settlement morphology, density, and typology}

Having grown organically, Kiandutu settlement lacks a structured pattern, though development mostly aligns with existing roads and footpaths (e.g., Athena Road, which is the main access road along Kiandutu's northwest edge, and directly links to Garissa Road). These and other primary roads and footpaths act as the main corridors for activities such as business, recreation, and transportation. Commercial activities are mostly found along the main arterial routes that lead to the main road and Mtatu village. Mtatu A\&B, Stage Wariah, and Mosque are Kiandutu's busiest villages, harbouring its major commercial activities, which decrease as one moves from west to east (i.e., from Mtatu to Molo), or as distance increases from Thika town.

The settlement has been built on irregular blocks of land, whose delineation corresponds with the road grid structure. The blocks generally measure about 385 square meters. Building structures form organic clusters with an average of eight units per block measuring between eight and 36 square metres each. Building orientation is predominantly northeast-southwest and northwest-southeast in terms of the longer axis of structures.

Building densities are higher in the northern and western parts of Kiandutu (e.g., Mtatu, Mosque, and Stage Warrior villages), and lower on the southern and eastern parts (e.g., Molo and parts of Mikinduri villages) (Figure 4.4). The unit densities at village level range from a low of 54 to a high of 136 units per acre. The most congested villages are found closer to the main road, and are characterized by closely built, iron-sheet structures that each contain at least eight households.

Kiandutu's predominant house typology is terrace (row) housing, consisting of 3-12 single rooms in a line, with the rows of rooms arranged back-to-back. With an average structure containing eight rooms (units), the average unit density for Kiandutu informal settlement is 84 units per acre. The housing units are laid out in a parallel or interlocking formation, sometimes producing residual clusters with micro-courtyards (popularly referred to as the 'plot' type). There are also smaller and relatively newer house in-fills, with a randomized orientation. The average 


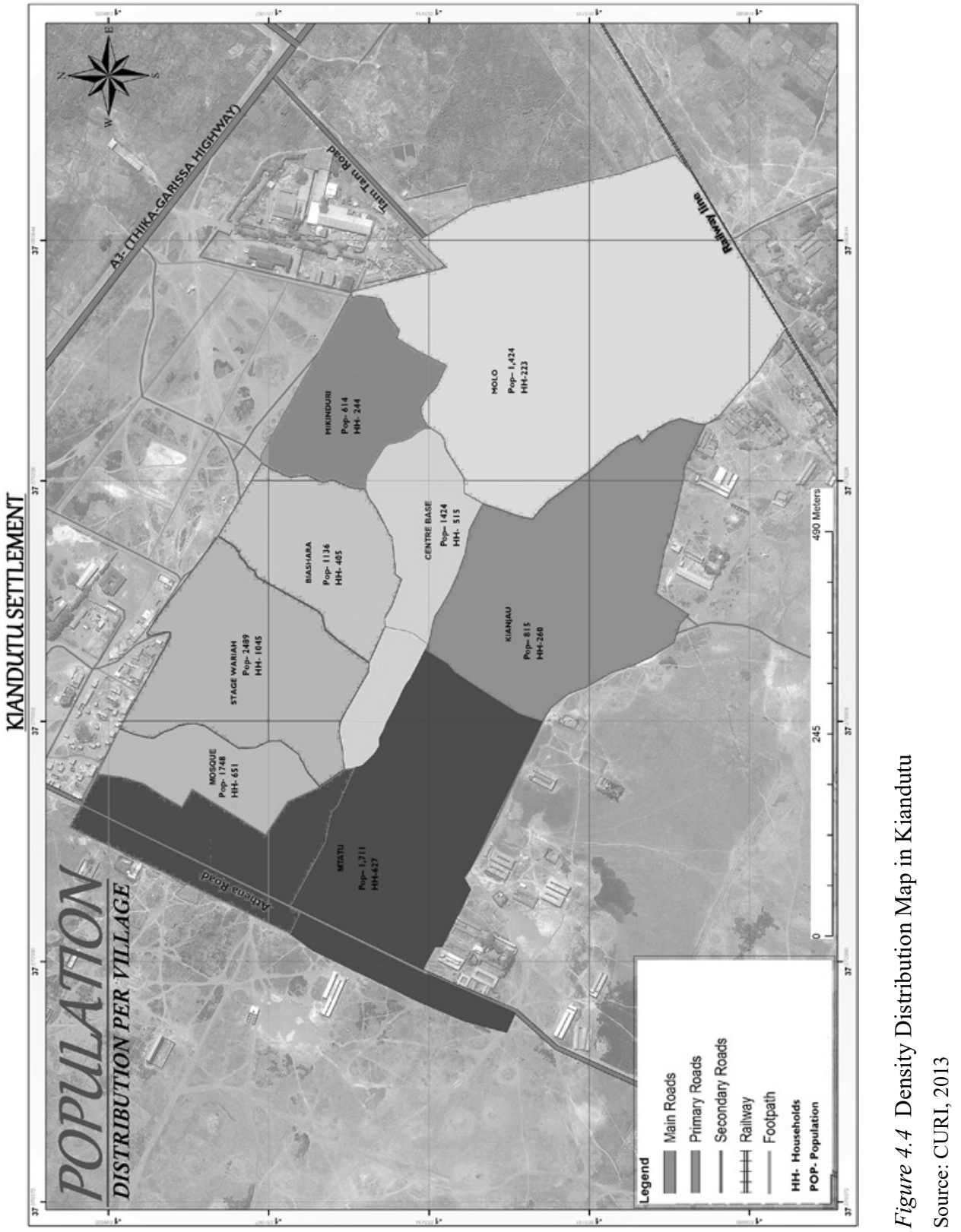


size of a room in the settlement measures $3 \mathrm{~m} \times 3 \mathrm{~m}$, with those used for businesses tending to be smaller.

The average occupancy per room is four persons. There are also special types of buildings serving as community facilities (churches, classrooms, eateries, etc.), whose sizes exceed that of a single room. The housing structures are predominantly temporary: single floor of either unfinished earth (94\%) or cement floor finish; walls of mud $(52.7 \%)$ or wood $(30.4 \%)$, and roofs of galvanized iron sheets (98\%).

The majority of the residents (53\%) are tenants paying rent (from Ksh5002,500). The majority (53\%) pay between Ksh500-1000, while 37\% pay rent of Ksh500. Rent values are determined by the house condition and the unit location, with structures that have services like electricity and those close to the roads attracting higher rent value.

\section{Infrastructure and utilities}

Access to infrastructure and other basic amenities is a challenge in Kiandutu. Although piped water is provided by Thika Water and Sewerage Company (THIWASCO), access is not provided at household level, and over $90 \%$ of the households rely on communal water points. The settlement's main water access challenges are high costs and an underdeveloped water reticulation network.

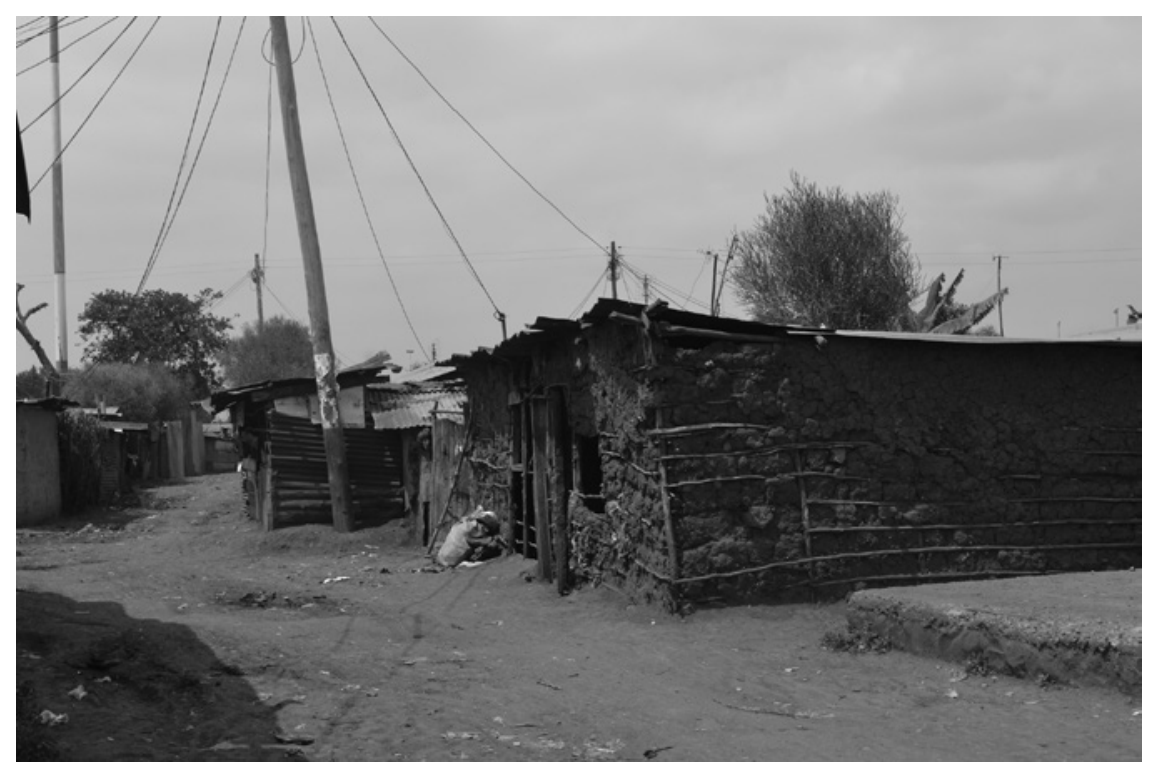

Figure 4.5 Temporary Housing in Kiandutu

Source: Authors 
In terms of energy access, $75 \%$ of residents access electricity for lighting (the majority being informal access), and $25 \%$ have no electricity at all. For cooking, $20 \%$ use paraffin and $60 \%$ charcoal as fuel.

There is a lack of storm water drainage and solid waste management facilities. Residents heavily rely on pit latrines for sanitation, with over $60 \%$ sharing. Informal methods are used in solid waste disposal, such as indiscriminate dumping/ burning of waste.

\section{Findings}

\section{On land sharing}

The CityLab was held with the Kiandutu community and other stakeholders to discuss various models and options for tenure security, including resettlement, community land buying, adverse possession, and land sharing. That said, the CityLab centred on the land-sharing option, which was extensively discussed with regard to its applicability and potential process in Kiandutu settlement. During the discourse, participants noted that they would be willing to support the landsharing option and process, provided the proper channels for community engagement and negotiations were put in place, and gentrification could be avoided. Key issues raised by stakeholders in the CityLab are discussed in more detail next.

\section{Perceived legitimate versus legal ownership}

Kiandutu presents a classic case of perceived legitimate ownership versus legal ownership. Some residents perceive themselves as legitimate landowners, as they were the original settlers after the purchase from colonial settlers in 1969. However, the law only recognizes title deeds as proof of individual ownership of land. In Kenya, a title deed also serves as a precondition for building development approval and all forms of land transactions. The fact that none of Kiandutu's residents possesses a registered title deed has ultimately led to the settlement's informal status, despite many residents having lived there for generations with a sense of perceived ownership. This issue of perceived ownership came up in the women's forum, where a participant stated: 'Kiandutu is the only home we know, most of us were born and found ourselves here, we have nowhere else to go and our families are here as well'.

\section{Impact of land tenure on investment}

Lack of secure tenure is known to discourage residents from investing either in improvements to their household environment, or in home-based activities that could alleviate poverty. The study saw this dynamic playing out in Kiandutu, where residents have made no attempts to improve their shelter conditions. Kiandutu residents live in semi-permanent, structurally unsound buildings constructed from mud or rusty galvanized iron. Economic investments in the settlement are 
Table 4.1 Summary of infrastructure-services conditions in Kiandutu

\begin{tabular}{|c|c|c|c|}
\hline $\begin{array}{l}\text { Infrastructure/ } \\
\text { service }\end{array}$ & Coverage/ Quality & $\begin{array}{l}\text { Key actors/ } \\
\text { Providers }\end{array}$ & Challenges \\
\hline Water & $\begin{array}{l}\text { Piped water available; } \\
\text { over } 90 \% \text { rely on } \\
\text { Communal Water } \\
\text { Points }\end{array}$ & $\begin{array}{l}\text { Thika Water } \\
\text { and Sewerage } \\
\text { Company }\end{array}$ & $\begin{array}{l}\text { - High Cost } \\
\text { - Reticulation Network }\end{array}$ \\
\hline Transport & $\begin{array}{l}70 \% \text { Reliance on non- } \\
\text { motorized/para-transit } \\
\text { facilities }\end{array}$ & $\begin{array}{l}\text { Private/Informal } \\
\text { Undertakers; } \\
\text { Self Initiatives }\end{array}$ & $\begin{array}{l}\text { - Poor Road Network } \\
\text { - Lack of Space for } \\
\text { Reticulation }\end{array}$ \\
\hline Sanitation & $\begin{array}{l}\text { Reliance on pit latrines, } \\
\text { with over } 60 \% \text { sharing; } \\
\text { lack of storm drainage } \\
\text { and solid waste } \\
\text { management facilities }\end{array}$ & $\begin{array}{l}\text { Community/ } \\
\text { Self; County } \\
\text { Government of } \\
\text { Thika (Sewer } \\
\text { Development) }\end{array}$ & $\begin{array}{l}\text { - High Cost } \\
\text { - Lack of Space for } \\
\text { Reticulation } \\
\text { - Accessibility/ } \\
\text { Servicing }\end{array}$ \\
\hline Health & $\begin{array}{l}\text { Informal within } \\
\text { settlement; formal } \\
\text { health centre outside } \\
\text { the settlement; up to } \\
75 \% \text { rely on informal } \\
\text { provision within } \\
\text { settlement for primary } \\
\text { health care }\end{array}$ & $\begin{array}{l}\text { Private } \\
\text { Undertakers } \\
\text { in Settlement; } \\
\text { Public \& } \\
\text { Private } \\
\text { Outside } \\
\text { Settlement }\end{array}$ & $\begin{array}{l}\text { - High Cost } \\
\text { - Traditional/ } \\
\text { Uncertified } \\
\text { Interventions } \\
\text { - Retrogressive } \\
\text { Community Attitudes } \\
\text { - Accessibility }\end{array}$ \\
\hline Education & $\begin{array}{l}93 \% \text { of school goers } \\
\text { attend formal } \\
\text { education; only } \\
5 \% \text { attend formal } \\
\text { secondary school; one } \\
\text { public primary school } \\
\text { within Kiandutu } \\
\text { Settlement }\end{array}$ & $\begin{array}{l}\text { Public and } \\
\text { Private } \\
\text { Undertakers }\end{array}$ & $\begin{array}{l}\text { - Poor Infrastructure } \\
\text { Conditions } \\
\text { - Substandard Quality } \\
\text { of education } \\
\text { - High Cost }\end{array}$ \\
\hline Solid Waste & $\begin{array}{l}\text { Informal methods; } \\
\text { indiscriminate } \\
\text { dumping/ burning of } \\
\text { waste }\end{array}$ & Community/Self & $\begin{array}{l}\text { - Lack of Infrastructure } \\
\text { - Retrogressive } \\
\text { Community Attitudes }\end{array}$ \\
\hline Energy & $\begin{array}{l}75 \% \text { access electricity } \\
\text { (majority being } \\
\text { informal access); } \\
20 \% \text { use paraffin and } \\
60 \% \text { charcoal as fuel }\end{array}$ & $\begin{array}{l}\text { Public } \\
\text { Undertakers; } \\
\text { Illegal } \\
\text { Middlemen/ } \\
\text { Brokers/ } \\
\text { Connectors }\end{array}$ & $\begin{array}{l}\text { - High Cost } \\
\text { - Lack of Space for } \\
\text { Reticulation } \\
\text { - Accessibility/ } \\
\text { Servicing } \\
\text { - Environmental } \\
\text { Concerns }\end{array}$ \\
\hline Security & $\begin{array}{l}12 \text { lighting masts at } \\
\text { strategic positions; } \\
\text { only one street } \\
\text { furnished with } \\
\text { lighting }\end{array}$ & $\begin{array}{l}\text { Public } \\
\text { (Police) and } \\
\text { Community- } \\
\text { led }\end{array}$ & $\begin{array}{l}\text { - Fear of Victimization } \\
\text { - Poor Accessibility/ } \\
\text { Navigation } \\
\text { - Lack of Infrastructure }\end{array}$ \\
\hline
\end{tabular}


limited to small shanties used as retail shops and groceries, or water vending shops that are similarly structurally unsound. Participants highlighted this scenario in the workshops, expressing fear of investing in the settlement due to their insecure tenure status. One participant from the men's forum argued:

This is not my place, it belongs to the government, so I cannot say it is my home because this land does not belong to anyone. If I am told to move away, I will move because it is not our home, as we do not have the title deed for us to settle here.

Similarly, a youth workshop participant noted:

We cannot build storey or high-rise houses because we are uncertain if we will be here tomorrow. But if we are assured and everyone is given a title deed, we can build such storey buildings

\section{Fears around land sharing}

Generally, residents' lack of secure tenure had a negative impact on their initial acceptance of the land-sharing approach, due to long-standing fears about losing the limited rights they do have to the land. Participants in all three workshops expressed concern over the likelihood of rich individuals infiltrating and then excluding them from the process. They also noted the possibility that the list of land-sharing beneficiaries could be changed, and other persons not residing in the settlement could be introduced to benefit. The fears raised by Kiandutu community have also been witnessed in other informal settlement upgrading programs. These fears and perceptions impeded the community's acceptance of the land-sharing concept, initially causing people to state a preference for the more conventional securing of tenure through titling, despite the difficulties inherent to that process.

\section{Morphology, density, and land sharing}

Differing village structures and varying population densities impacted participants' attitudes towards the land-sharing approach. For example, some workshop participants felt that should they adopt land sharing, the less densely inhabited village clusters should be taken by the County Government, as the process of relocation would then cost less. There was general agreement that the County Government should consider taking areas that are inhabitable due to steep slopes, susceptibility to flooding, and proximity to the railway line (e.g., parts of Molo Village).

\section{On planning considerations}

In the workshops, the CURI team explained that as a policy option, land sharing offers slum settlement dwellers faced with imminent eviction and tenure insecurity 
a strategy by which they can organize, lobby, and bargain for a share of the land they already occupy. Such bargaining would occur with the landowner (either a private entity or the state). Following negotiations, the landowner can agree to sell or lease all or part of the land in question to the slum dwellers.

Because Kiandutu is located on public land, any such negotiations would need to comply with Section 12 of the Land Act 2012, which provides that the National Land Commission may, on behalf of the national or county governments, allocate public land by way of, among others, applications confined to a targeted group or groups of persons, in order to ameliorate their disadvantaged position. This provision provides sufficient legal grounds for the Kiandutu community and the County Government of Kiambu to negotiate a land-sharing deal.

For a land-sharing option between Kiandutu residents and the County Government to be viable, the workshops identified five further principles as fundamental:

\section{The informal settlement community must be well-organized}

Organization will enable the community's ability to bargain effectively in the negotiations for land sharing. Land sharing is not successful where communities are weak, as once implemented, a plethora of challenges can arise around numerous issues, including resale of some houses (which then command a higher market value); conflict over beneficiaries; and noncompliance to the land-sharing agreement.

A 2013 CURI study found that only $15 \%$ of all adults in Kiandutu are members of formal community organizations. The study attributed these numbers to the fact that Kiandutu, like many informal settlements in Kenya, is a community with high levels of apathy and low levels of trust and unity - suspicion is common and exacerbated by poor leadership and various forms of corruption. It is our conclusion that this attitude together with different priorities at both individual and collective levels can compromise collective action as a possible strategy to enhance collective initiatives.

\section{A clearly documented land-sharing agreement must be in place}

The land-sharing agreement must be negotiated, clearly documenting aspects such as the portion of land allocated to the landlord and community, the preferred tenure, how the land will be managed and administered by the parties, and how conflict will be resolved, among other issues. Negotiating a land-sharing agreement is usually a protracted process requiring the commitment of an informed and well-organized community leadership.

\section{Residents must accept that densification will occur}

Land-sharing agreements will rehouse the community over a smaller total area, and therefore require higher/increased residential densities. The community 


\section{2}

Peter Ngau and Philip Olale

has to accept the likelihood of vertical densification, and the fact that they will not all occupy an individual and independent piece of land. This vertical densification argument was discussed and supported across the three CityLab workshops.

\section{Residents must accept that reconstruction will be required}

The increase in density and the need to clear part of the site usually necessitates the reconstruction of houses (Figure 4.6). This was discussed in the men's workshop, with a participant noting that if land sharing is to be adopted, the most suitable model would be multistorey housing developments. The need for both densification and reconstruction necessitates the preparation of a Special Area Physical Development Plan that clearly illustrates details such as the level of densification, plot ratios and setbacks, preferred housing typologies, etc. ${ }^{7}$

Based on our analysis of the preferred scenarios expressed by the CityLab participants, Figure 4.6 illustrates a possible outcome of a negotiated land-sharing planning process. In this outcome, the County could potentially recover 49 acres, while the remaining 51 acres would go to the community. Such a planning process would take time and require support from the County Government, which is also responsible for development control. Additionally, support would be needed to facilitate the adoption of planning and building standards that are appropriate to an informal settlement, but would not adversely compromise public health.

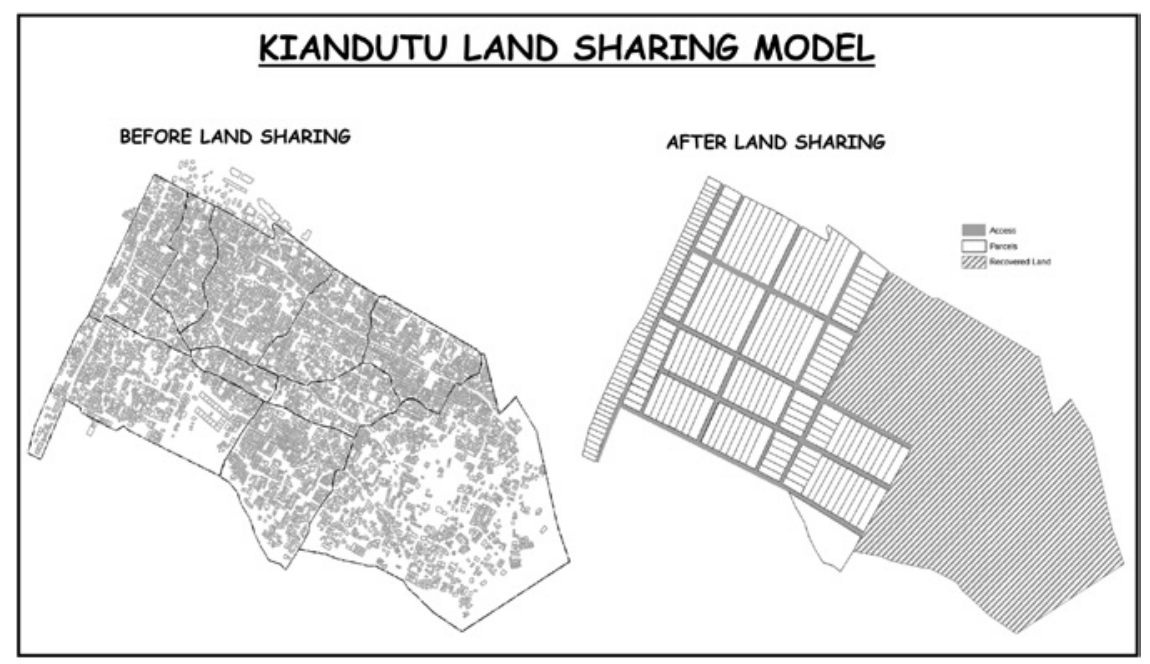

Figure 4.6 Land Sharing Scenario

Source: Authors 


\section{Capital is needed}

The land-sharing processes discussed earlier all require capital - either from the community's domestic savings or in the form of loans from outside sources and the ability to access capital will be tied to the community's organizing and mobilizing capacity. Resource mobilization in Kiandutu is currently focused on income-generating activities, savings, and establishing a revolving fund. Mobilizing networks such as Kiandutu Residents Association and Muungano wa Wanavijiji (the federation of slum dwellers) already exist, but membership remains low and needs to grow to a settlement-wide scale. For a land-sharing agreement to work, there is a need for increased sensitization and a fairly good level of coordination, cooperation, and buy-in for community-based initiatives.

\section{Analysis, recommendations, and lessons}

\section{Implications of a land-sharing solution for Kiandutu}

Land sharing is as simple as it is complex. Its simplicity stems from the existence of two (or more, in certain situations) contesting parties, who want to reach an amicable solution to the challenge of ownership and tenure security. Complexity arises in the process, which requires a united community voice, lengthy negotiations, and subsequent land surveying and settlement planning. All of these processes demand resources, both in time and finances. The Kiandutu CityLab found that land sharing as a way to attain sustainable security of tenure will likely be more complex than simple, due to the following key issues:

\section{Lack of understanding of land-sharing concept}

Although land sharing is not an entirely new concept, it has not been widely applied in Africa and specifically Kenya. Although the land-sharing approach offers the prospect of a 'win-win-win' solution for all main parties involved, informal settlement residents occupying government land often continue to prefer individual tenure through titling over land sharing. That said, the process of titling requires formal surveys and a rigorous land management and regulatory framework - an expensive prerequisite that many informal settlement dwellers cannot afford. In addition, it should be noted that titling may be detrimental to some households living in informal settlements, especially those with vulnerable legal and social status; for example, tenants/subtenants on squatter land, newly established occupants who are not considered eligible, single young men and women, and female heads of households.

While the experience of case studies, such as those in India and Thailand, may prove a useful starting point, it is worth noting that tenure issues in informal settlements in Kenya specifically, and sub-Saharan Africa generally, tend to be more contentious. In the case of Kiandutu settlement, the lack of understanding of the land-sharing concept was distinctly revealed. For example, the community 


\section{4}

wondered why they should share the land, despite a common understanding that it is public land. In addition, while typical land-sharing agreements return the more commercially attractive part of the site to the registered landowner (in this case, Kiambu County Government), community members in Kiandutu preferred to give the County the least attractive or economically viable land in the settlement.

\section{Concerns and fears of externalities from the land sharing process}

Slum dwellers live in perpetual fear of eviction and therefore understandably approach any external intervention with a sceptical eye. The Kiandutu community viewed land sharing as a lengthy process, during which they feared the settlement might be opened to land grabs by affluent members of the wider society, and subsequently lead to gentrification. They also feared the possibility that approaching the government with the idea of land sharing would reignite the government's interest in repossessing the land. Finally, the community also raised concerns over the possibility that its poor and marginalized members ultimately would be excluded from the land-sharing process, should it be adopted.

\section{Lack of trust in public processes}

Trust in governance, public processes, and public actors and institutions is fundamental to legitimize state action, and the lack of trust presents a massive obstacle to public policy and development. Studies have shown that citizens' mistrust of public process emanates from widespread corruption in public institutions in Africa (Armah-Attoh et al., 2007). The land-sharing process entails the government acting as a third-party beneficiary between the community and the landowner. However, in the case of Kiandutu, the County Government of Kiambu is also the landowner.

The land-sharing process also requires surveying, planning, densification, and/or resettlement, which all necessarily involve public institutions. According to the Kiandutu community, government involvement in tenure negotiations and housing initiatives would make these processes susceptible to corrupt deals made in 'top offices'. As such, the community fears that such deals could condemn them to losing the land or getting locked out of any benefits accruing from the process.

\section{Lack of a strong community organization}

Land sharing relies on strong community organization and the community's ability to negotiate effectively with the landowners to create a 'win-win' situation for both parties (Parry, 2015; Srinivas, 2015). In the CityLab workshop, Kiandutu community members said that they lacked a strong community organization, 
which will likely be required to champion negotiations. Currently the only visible organization is Muungano wa Wanavijiji, which only has a few members, and cannot effectively represent the whole community's issues when called upon. In the women's workshop, it was noted that there is a need to develop a shared vision, given that other organizations exist within the community (besides Muungano), and they all have different goals pertaining to land matters. The lack of strong community organization also impedes the community's ability to raise the necessary funds for a land-sharing process.

\section{Structure owners/landlords-tenants dichotomy}

In Kiandutu, a landlord-tenants dichotomy exists, and we found that landlords (or more accurately 'structure owners', who in Kiandutu can own a structure without having title to the land) felt entitled to a bigger share of the potential land-share plots than the tenants. The landlords' sense of entitlement stems from having settled earlier, being in-born (seeing their claim as a birth right), or having invested in the settlement. By the same token, tenants felt entitled to the land they reside on in Kiandutu, with some having rented for a lengthy period of time.

\section{Recommendations}

These recommendations were mainly derived from the Kiandutu CityLab community engagements. They represent the knowledge, expertise, thoughts, sentiments, and feelings shared by the community concerning land sharing as a sustainable approach to tenure security in Kiandutu. These sentiments were then supplemented by existing literature and case studies on successful land-sharing approaches in settings similar to Kiandutu.

\section{Promote broad-based community involvement/participation}

The participation of the Kiandutu community in improving the quality of its settlement is an important resource that must be tapped for this settlement's long-term sustainability. This will be in line with global agreements such as the New Urban Agenda, which have been locally adopted to promote equity and inclusion in human settlement development and urban poverty mitigation measures. Ideally, community participation cuts down the high cost associated with traditional community development approaches, monetary and human-power constraints, and supports the realization that local solutions can be effective. In addition, community participation provides an opportunity for developing solidarity in the struggle against oppression and resultant marginalization in the community. In light of this, special emphasis must be made to develop ways to ensure that the needs of marginalized groups in Kiandutu are taken into consideration throughout the entire land-sharing process so that no one is excluded from the benefits. 


\section{Redefine the role of third parties in fostering a strong community organization}

Strong community organization is an important ingredient in the negotiations that are integral to the land-sharing process. This is because community organizations present a unified front to the landowner during negotiations, discouraging the latter from exploiting differences among residents, and/or attempting to buy off certain community members (Rabé, 2010). More often than not, community strength increases through alliances with local organizations, NGOs, human rights groups, political parties, and other groups that may give the community cause more visibility (Rabé, 2010).

Given the current situation in Kiandutu and its existing intra-community dichotomies, the role of nongovernmental and voluntary organizations must be emphasized in mobilizing the people into an organization, training and educating them, forming a link with the authorities, and in various other catalytic ways (Srinivas, 2015).

\section{Develop an effective community financing strategy}

The land-sharing process requires finances for surveying, planning, and redeveloping the settlement. In Kiandutu, options for financing may be two-fold: the residents may opt to let the government finance the housing redevelopment, and pay that back through rent; or the community may join to pool resources and finance the process. Whichever financing model the Kiandutu community opts for, it is imperative to centre it on a firm foundation of community-based savings and/or loan systems along with County Government commitments.

\section{Community organization}

As mentioned, for land sharing to succeed, strong community organization with a clearly defined vision and leadership structure that the community trusts to negotiate on its behalf is vital. However, like many informal settlements, Kiandutu currently lacks such organization. Because the existing community groups have different interests, dialogue initiatives must be carefully crafted to ensure that they do not become a source of conflict in these small and disaggregated groups.

\section{Create checks and balances in the existing institutional structures}

The institutions involved in the process (including the national and county government departments) must commit to transparency and ensure public participation and involvement. These efforts must also be coupled with strong commitments to accountability and public information sharing. This helps to ensure the sustainability of the land-sharing effort, and reduces the possibility that laudable goals are subverted by other interests. 


\section{Ensure and implement a holistic approach to land sharing as an option to tenure security improvement}

During the planning phase of the process, intensive and efficient land-use planning that promotes economic growth and empowerment of the Kiandutu community is a necessity. As noted by Montressor (2015), there should also be comprehensive reforms geared towards regulating the urban land market, restricting land uses, and enabling incremental upgrading of the settlement.

\section{Lessons from CURI CityLab}

As a method of co-production, the CityLab approach requires effective participation from both the government agencies and the informal settlement dwellers. Key factors - political, institutional, as well as social and community-organization based - that affected the success of Kiandutu Settlement CityLab are listed here, in the hopes that they might inform future similar efforts.

\section{Strong community collaboration}

Since 2007, CURI, which started as a project called Urban Innovations Project (UIP), has worked with various informal settlements including Kiandutu through collaborations with local community organizations, NGOs, international partners, and government agencies. Through continuous engagement with the Kiandutu community and these other stakeholders, CURI succeeded in building trust and being seen as a neutral partner. The success of the Kiandutu Settlement CityLab co-production process hinged on this acceptance and trust on the part of the community.

\section{Timing}

Given Kenya's historical injustices, land is a very emotive issue, and the Kiandutu settlement presents a typical case of perceived land injustice. The CityLab dialogues informing this study were held against the backdrop of a national electioneering period - a period when any discussions centred on land issues were liable to solicit suspicion or volatile reactions. Planning for future similar CityLab work should therefore factor in the political environment, and devise methodologies that can mitigate against political influence. One way to do this would be to ensure that such projects do not coincide with election years.

\section{Changes to political leadership}

While Kenyan national elections are held every five years - often bringing a shift of power(s) and resultant personnel changes in key government institutions - land sharing is a lengthy process that may extend beyond the five-year term of any given administration. It is important to note that when personnel change, the new 
team may not necessarily be amenable to the previous government's interests and priorities. Such shifts may unnecessarily frustrate the land-sharing process, potentially leading to an impasse.

\section{Conclusion}

There is an urgent need to address and resolve the formal-informal sector division and resultant poor relations that collectively constrain efforts to advance informal settlement upgrading in Kenya today. This shift will require practical, negotiated approaches to tenure security, access to land rights, and tenure regularization, which also understand and respond to local conditions and factors. The aim of this CityLab was to co-produce an innovative approach to securing land tenure through land sharing. Even though land sharing has the potential to unlock the current tenure situation in Kiandutu, its adoption as a policy strategy still faces challenges. These challenges emanate from the majority of the slum dwellers being unaware of the actual mechanisms of land sharing; the enormity of the resources needed for successful implementation of a land-sharing agreement; and the degree of mistrust from the community towards government. There are also challenges that relate to the County Government of Kiambu as the legal custodian of the land. It was noted that support of tenure regularization in Kiandutu depended on the goodwill of specific officers, and not through a deliberate county programme. The issue here is that when such officers leave either due to transfer or regime change (following the five-year cycle of elections), supportof the community process would also dissipate.

Despite these significant obstacles, a major takeaway from this CityLab was that Kiandutu slum dwellers are willing to engage in land sharing as an innovative way of securing their tenure. Providing a framework that can be leveraged by both the national and county governments in Kenya, this CityLab thus presented an option for tackling land access constraints faced by the urban poor in securing respectable, sustainable shelter. Key to this success was the presence of a trusted third party that is seen as neutral in the land contestation question, and thus could create an atmosphere conducive to participatory and inclusive dialogue. However, this CityLab also demonstrated that the community always prefers to own the land in its entirety, and that any other approach to securing tenure such as land sharing would only succeed after the community is convinced that it is the only viable option.

The CityLab provided the Kiandutu community and the technical experts involved with platforms for knowledge and information exchange. Able to engage in deeper discussions with the community about their daily challenges and how they felt these could be addressed, the technical experts were able to rationalize their expert opinions with those of the community, especially concerning scenarios for a potential land-sharing outcome. The Kiandutu community similarly benefited from receiving technical input about land sharing directly from professionals engaged in such processes. Through the workshops, the community members were trained in the tenets of the land-sharing approach, their roles in the 
process, and potential benefits. This enabled the community to gain vital skills germane to the implementation and monitoring of progress and change within their settings, should the land sharing approach be adopted. The CityLab underscored that communities living and experiencing tenure security challenges are the actors best suited to inform and document changes taking place in the settlements before and after any interventions. The CityLab methodology also offers government (national and county), partner organizations, and technical experts a platform to gauge the effectiveness of a proposal and intervention for tenure regularization, helping to ensure that policy intervention for slum dwellers are negotiated and co-produced.

Finally, the Kiandutu CityLab demonstrated the urgent need to add new methodologies to the university planning curriculum and training framework for urban studies. Such a new framework should target a better appreciation of urban informality through continuous discourse and engagement with key stakeholders. In sum, the research presented in this chapter demonstrates the value of and need for a more practical and effective type of university training for urban planners in Africa; this necessarily involves the academy opening to communities to facilitate direct contact and experiential learning to enrich the relevance of the curriculum and the overall contribution of the university to societal development, which in turn will further the agenda of inclusive and sustainable urban development on the continent.

\section{Notes}

1 The Government is yet to release disaggregated 2019 data based on urban rural population.

2 Kenya Vision 2030 is the government's development blueprint. Covering the years 2008-2030, its aim is to transform Kenya into a newly industrializing, middle-income country, providing all citizens a high quality of life in a clean and secure environment by 2030 .

3 Sessional Paper No. 3 of 2009.

4 This land is now public land under the custody of County Government of Kiambu, based on the devolved system of government under the Constitution of Kenya 2010.

5 The Chief is considered a representative of national government.

6 An official register showing details of ownership, boundaries, and value of real property in a district, made for taxation purposes.

7 Special Area Physical Development Plans are affected by the Physical Planning Act, Section 23, which mandates the declaration of areas with unique development potential or problems as Special Planning Areas.

\section{References}

Abott, J. (1996). Sharing the city: community participation in urban management. London: Routledge. DOI: https://doi.org/10.4324/9781315070759

Angel, S. \& Boonyabancha, S. (1988). Land sharing as an alternative to eviction: the Bangkok experience. Third World Planning Review, 10(2), pp. 107-127. DOI: https://doi. org/10.3828/twpr.10.2.v54j0130h27j4r32 


\section{0}

Peter Ngau and Philip Olale

Armah-Attoh, D., Gyimah-Boadi, E. \& Chikwanha, A. (2007). Corruption and institutional trust in Africa: implications for democratic development. Working Papers No. 81. Afrobarometer. Retrieved: https://afrobarometer.org/sites/default/files/publications/ Working\%20paper/AfropaperNo81.pdf

Boonyabancha, S. (2005). Baan Mankong: going to scale with 'slum' and squatter upgrading in Thailand. Environment and Urbanization, 17(1), pp. 21-46. DOI: http://dx.doi. org/10.1177/095624780501700104

Buckely, R.M. \& Kalarickal, J. (2006). Thirty years of world bank shelter lending: what have we learned? Washington: World Bank. DOI: https://doi.org/10.1596/978-0-8213-6577-9

Clarke, R.A. (2009). Securing communal land rights to achieve sustainable development in sub-Saharan Africa: critical analysis and policy implications. Law, Environment and Development Journal, 5(2), pp. 130-151. Retrieved: www.lead-journal.org/con tent/09130.pdf.

CURI. (2013). Kiandutu settlement profile. Nairobi: Centre for Urban Research and Innovations (CURI).

D'Cruz, C., Mcgranahan, G. \& Sumithre, U. (2009). The efforts of a federation of slum and shanty dwellers to secure land and improve housing in Moratuwa: from savings groups to citywide strategies. Environment \& Urbanization, 21(2), pp. 367-388. DOI: https:// doi.org/10.1177\%2F0956247809342360.

De Soto, H. (2000). The mystery of capital: why capitalism triumphs in the west and fails everywhere else. New York: Basic Books.

Durand-Lasserve, A. (2004). Land for housing the poor in African cities: are neo-customary processes an effective alternative to formal systems? In: Hamdi, N. (Ed.), Urban futures: economic growth and poverty reduction. Rugby: ITDG Publishing, pp. 160-174.

Durand-Lasserve, A. \& Royston, L. (Eds.). (2002). Holding their ground: secure land tenure for the urban poor in developing countries. London: Earthscan. DOI: https://doi. org/10.1016/S0197-3975(03)00033-X

Enemark, S. (2016). Sustainable land governance in support of the global agenda. ILMI Working Paper No. 3, Windhoek. Namibia: Integrated Land Management Institute, Namibia University of Science and Technology, pp. 1-10.

Friedmann, J. (1987). Planning in the public domain: from knowledge to action. Princeton: Princeton Univeristy Press.

Government of Kenya (GoK). (2009). Sessional paper no. 3 of 2009 on national land policy. Nairobi: Government Printer.

Government of Kenya (GoK). (2010). Constitution of Kenya. Nairobi: Government Printer.

Government of Kenya (GoK). (2012). Land act. Nairobi: Government Printer.

Government of Kenya (GoK). (2017). Kenya's popular version of the new urban agenda: towards inclusive, safe, resilient and sustainable cities and human settlements. Ministry of Transport, Infrastructure, Housing and Urban Development. Retrieved: www.kara. or.ke/Kenya $\% 27 \mathrm{~s} \% 20$ Popular\%20Version $\% 20$ on $\% 20$ New $\% 20$ Urban $\% 20$ Agenda.pdf

Healey, P. (2006). Colaborative planning: shaping places in fragmented societies. New York: Palgrave Macmillan.

Huchzermeyer, M. (2011). Cities with slums: from informal settlements eradication to a right to the city in Africa. Cape Town: University of Cape Town Press.

KNBS. (2009). Kenya population and housing census 2009: volume I. Nairobi: Kenya National Bureau of Statistics (KNBS).

KNBS. (2019). Kenya population and housing census 2019: volume I. Nairobi: Kenya National Bureau of Statistics (KNBS). 
Komjathy, K., Nichols, S.E. \& Ericsson, A. (2001). Principles for equitable gender inclusion in land administration: fig guidelines on women's access to land (Fig Publication No. 24). Frederiksberg, Denmark: International Federation of Surveyors. Retrieved: www.fig.net/resources/proceedings/fig_proceedings/korea/full-papers/pdf/session6/ komjathy-nichols-ericsson.pdf

Montressor, F. (2015). Preconditions of land sharing and development of the principle. Retrieved: www.hdm.lth.se/fileadmin/hdm/Education/Undergrad/ABAN06_2013/Mon tresor_Francesco.pdf

Napier, M., Berrisford, S., Kihato, C.W., McGaffin, R. \& Royston, L. (2013). Trading places: accessing land in African cities. Somerset West: Urban LandMark and African Minds.

Olale, P.O. (2015). Implications of land tenure security on sustainable land use in informal settlements in Nairobi. Nairobi: University of Nairobi.

Olale, P.O. \& Opiyo, R.O. (2017). Policy brief: alternatives to eviction, scenarios for access to land by the urban poor in Kiandutu informal settlement Thika, Kenya. Nairobi: Centre for Urban Research and Innovations, University of Nairobi.

Parry, J. (2015). From slums to sustainable communities: the transformative power of secure tenure. Issue Paper on Secure Tenure for Urban Slums. Habitat for Humanity. Retrieved: https://www.habitat.org/sites/default/files/issue-paper.pdf

Payne, G. (Ed.). (2002). Land, rights and innovation: improving tenure security for the urban poor. London: ITDG Publishing.

Payne, G., Durand-Lasserve, A. \& Rakodi, C. (2009). The limits of land titling and home ownership. Environment and Urbanization, 21(2), pp. 443-462. DOI: https://doi.org/10. $1177 / 0956247809344364$

Rabé, P.E. (2005 December 8-9). Land sharing in phnom penh: an innovative but insufficient instrument of secure tenure for the poor. Paper presented at Expert Group Meeting on Secure Land Tenure: New Legal Frameworks and Tools UN-ESCAP, Bangkok, Thailand.

Rabé, P.E. (2010). Land sharing in Phnom Penh and Bangkok: lessons from four decades of innovative slum redevelopment projects in two Southeast Asian boom towns. Washington, DC: World Bank.

Rakodi, C. (2014). Expanding women's access to land and housing in urban areas. Gender Equality and Development, Women's Voice and Agency Research Series, 8, pp. 1-56.

Rudd, A., Simon, D., Cardama, M., Birch, E.L. \& Revi, A. (2018). The UN, the urban sustainable development goal, and the new urban agenda. In: Elmqvist, T. (Ed.), The urban planet: knowledge towards sustainable cities. Cambridge: Cambridge Univeristy Press, pp. 180-196.

Scholl, C. \& Kemp, R. (2016). City labs as vehicles for innovation in urban planning processes. Urban Planning, 1(4), pp. 89-102. DOI: https://doi.org/10.17645/up.v1i4

Sorrenson, M.P. (1967). Land reform in the Kikutu County: a study in government policy. Nairobi: Oxford University Press.

Srinivas, H. (2015). Urban squatters and slums: defining squatter settlement. Kobe, Japan: Global Development Research Center. Retrieved: www.gdrc.org/uem/squatters/definesquatter.html

Syagga, P.M. (2011). Land tenure in slum upgrading projects. In: Les cahiers d'Afrique del'Est. Nairobi: French Institute for Research in Africa (IFRA), pp. 103-113.

Tacoli, C., McGranahan, G. \& Satterthwaite, D. (2015). World migration report 2015: urbanization, rural-urban migration and urban poverty. London: International Organization for Migration. 


\section{Peter Ngau and Philip Olale}

UN-Habitat. (2010). The state of African cities 2010: governance, inequality and urban land markets. Nairobi, Kenya: United Nations Human Settlements Programme (UN-Habitat).

Vogiazides, L. (2012). 'Legal empowerment of the poor'versus 'right to the city'. Uppsala: The Nordic Africa Institute. Retrieved: http://urn.kb.se/resolve?urn=urn\%3Anbn\%3As e\%3Anai\%3Adiva-1560

Watson, V. (2002). The usefulness of normative planning theories in the context of subSaharan Africa. Planning Theory, 1(1), pp. 27-52. DOI: https://doi.org/10.1177/ 147309520200100103 